\title{
الأداء الحركي المائي لشبكة الجر القاعى التقليدية في كوتا بارو من خلال تجربة خزان المر المائي
}

\author{
أحمدي \\ كلية علوم البحار والمصايد - جامعة لامبونج - إندونيسيا
}

المستخلص: تم دراسة الأداء الحركي المائي لنموذج بمقياس إ: 1 من شبكة جر قاعي تقليدي في خزان ممر مائي.

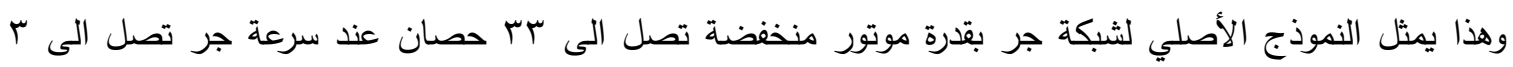

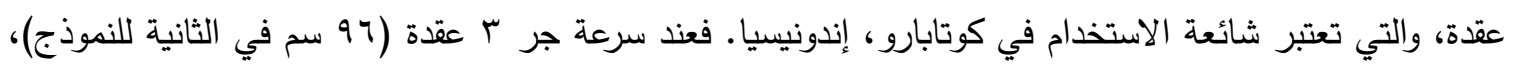

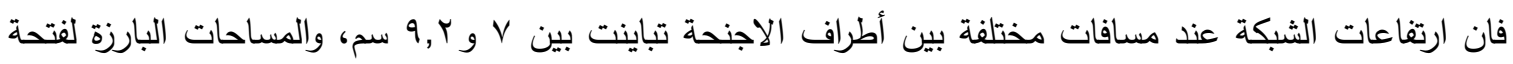

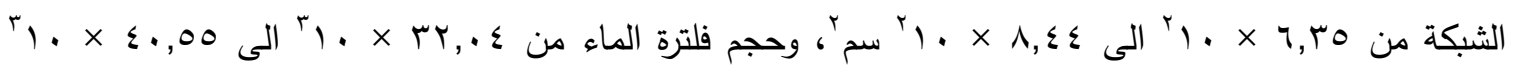

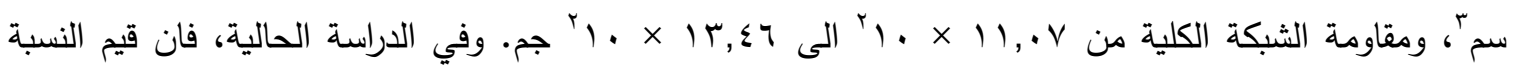

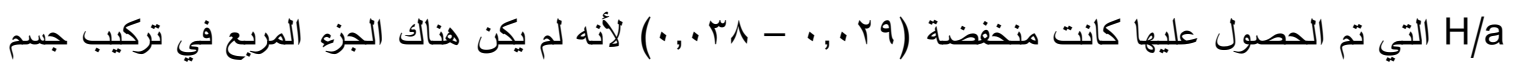

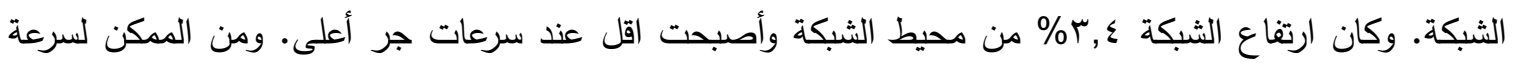

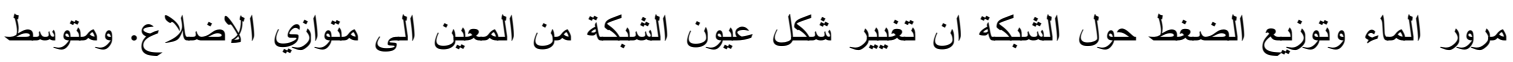

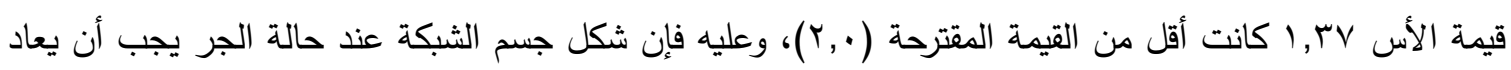
تحديدها. كلمات دالة: مقياس نموذج، خزان ممر مائي، كفاءة الثبكة، محيط الشبكة، شبكة جر قاعي، كوتا بارو. 
construction relating to the net mouth height I. Bulletin Tokai Reg. Fisheries Research Laboratory, 91: 53-66.

Özbilgin, Y. D., Kalecik, E., Bozaoğlu, A. S., Eryaşar A. R., Gökçe, G. and Özbilgin, H. (2013) Observation of fish behavior during demersal trawling operations in the North Eastern Mediterranean. In: Proceedings of the Symposium: Impacts of Fishing on the Environment ICES-FAO Working Group on Fishing Technology and Fish Behaviour Bangkok, Thailand, 6-10 May 2013.

Prat, J. Antonijuan, J., Folchb, A., Salac, A., Lucchetti, A., Sardàd, F. and Manuel, A. (2008) A simplified model of the interaction of the trawl warps, the otterboards and netting drag. Fisheries Research, 94: 109-117. doi:10.1016/j.fishres.2008.07.007

Reid, A. J. (1977) Scottish fisheries research report. 7: 1-12.

Sala, A. and Lucchetti, A. (2011) Effect of mesh size and codend circumference on selectivity in the Mediterranean demersal trawl fisheries. Fisheries Research, 110: 252-258. doi:10.1016/j.fishres.2009.07.004

Shahardin, Z. A. (1983) Model experiments on small shrimp trawls. Feasibility studies on the double rigged type over the single rigged type. Master Thesis, Faculty of Fishery Kagoshima University, Japan, 137 pp.

Sterling, D. (2009) Fishing Energy Efficiency Review for the Fisheries Research and Development Corporation. FRDC Rep. 2005/239.

Stewart, P. A. M. and Ferro, R. S. T. (1985) Measurements on gill nets in a flume tank. Fisheries Research, 3: 2946.

Suzuki, K., Takagi, T., Shimizu, T., Hiraishi, T., Yamamoto, K. and Nashimoto, K. (2003) Validity and visualization of a numerical model used to determine dynamic configurations of fishing nets. Fisheries Sciences, 69(4): 695-705

Takahashi, Y., Fujimori, Y., Hu, F., Shen, X. and Kimura, N. (2015) Design of trawl otter boards using computational fluid dynamic. Fisheries Research, 161: 400-407

Tauti, M. (1934) A relation between experiments on model and on full scale fishing net. Bulletin Japanese Society of Fisheries Science, 3: 171-177.

Walsh, S. J. (1996) Efficiency of bottom sampling trawls in deriving survey abundance indices. NAFO Scientific Council. Studies, 28: 9-24. 
Christensen, B. A. (1974) Hydrodynamic modeling of nets and trawls. Engineering and Industrial Experimental Station. University of Florida, USA. p. 28-35.

Dereli, H., Aydin, C., Bell, M., Kebabcioglu, T., Akpinar, I. O. and Sen, Y. (2016) Selectivity of commercial and experimental codends for the demersal trawl fishery of the deep-water rose shrimp, parapenaeus longirostris (Lucas, 1846), in the Aegean Sea. Crustaceana, 89(4): 477-493.

Ebata, K., Teraji, S. and Okino, A. (2013) Reduction of hydrodynamic force acting on bottom trawl net. In: Proceedings of the Symposium: Impacts of Fishing on the Environment ICES-FAO Working Group on Fishing Technology and Fish Behaviour, Bangkok, Thailand, 610 May 2013.

Eliasson, J., Eliasson, E. B. and Eliasson, H. S. (2015) Hydrodynamic Assessment of Increasing the Energy Efficiency of Trawler Propulsion with a Draft Tube. Open Journal of Fluid Dynamics, 5: 139-144. http://dx.doi.org/10.4236/ojfd.2015.52016

Fiorentini, L., Sala, A., Hansen, K., Cosimi, G. and Palumbo, V. (2004) Comparison between model testing and full-scale trials of new trawl design for Italian bottom fisheries. Fisheries Sciences, 70: 349-359. http://dx.doi.org/10.1111/j.1444-2906.2004.00813.x

Fridman, A. L. (1986) Calculations for fishing gear designs. FAO Fishing Manuals, Fishing News Books Ltd., Farnham, Surrey, England.

Fuwa S., Ishizaki, M., Ebata, K. and Fujita, S. (2002) Fluid dynamic resistance for the trolling depressor. Fisheries Sciences, 68: 751-756.

Fuwa, S., Kude, S., Ebata, K. and Mizoguchi, H. (2013) A comparison of the fishing gear efficiency on the trawl with knotted and knotless net webbings. In: The Symposium on Impacts of Fishing on the Environment ICES-FAO Working Group on Fishing Technology and Fish Behaviour Bangkok, Thailand, 6-10 May 2013.

Harrington, D. L., Watson, J. W., Parker, L. G., Rivers J. B. and Taylor C. W. (1988) Shrimp trawl design and performance. The University of Georgia Marine Extension Service. Z Brunswick, Georgia, 37 pp.

He, P., Smith, T. and Bouchard, C. (2008) Fish behavior and species separation for the Gulf of Maine multispecies trawls. Journal of Ocean Technology, 3(2): 60-77.

He, P. and Balzano, V. (2012) Improving Size Selectivity of Shrimp Trawls in the Gulf of Maine with a Modified Dual-Grid Size-Sorting System. North America Journal of Fisheries Management, 32(6): 1113-1122. http://dx.doi.org/10.1080/02755947.2012.720642
He, P., Rillahan, C. and Balzano, V. (2014) Reduced herding of flounders by floating bridles: application in Gulf of Maine Northern shrimp trawls to reduce bycatch. ICES Journal of Marine Sciences: Journal du Conseil, fsu235.

Higo. (1971) Fundamental studies on the fishing efficiencies of the trawling nets. Memoirs of Faculty of Fishery, Kagoshima University Japan, 20: 1-137.

Hu, F. X., Matuda, K. and Tokai, T. (2001) Effects of drag coefficient of netting for dynamic similarity on model testing of trawl nets. Fisheries Sciences, 67: 84-89.

Khaled, R., Priour, D. and Billard J. Y. (2012) Cable length optimization for trawl fuel consumption reduction. Ocean Engineering, 58: 167-179.

Madsen, N. and Hansen K. E. (2001) Danish experiments with a grid system tested in the North Sea shrimp fishery. Fisheries Research, 52: 203-216.

Main, J. and Sangster G. I. (1985) The behaviour of the Norway lobster, Nephrops norvegicus, during trawling. Scottish Fishery Research Report, 24: 23.

McHugh, M. J., Broadhurst, M. K., Sterling, D. J. and Millar, R. B. (2015a) Comparing three conventional penaeid-trawl otter boards and the new batwing design. Fisheries Research, 167: 180-189.

McHugh, M. J., Broadhurst, M. K., Sterling, D. J. and Millar R. B. (2015b) A 'simple anterior fish excluder' (SAFE) for mitigating penaeid-trawl bycatch. PloS ONE 10(4): e0123124.

Mellibovsky, F., Prat, J., Notti, E. and Sala, A. (2015) Testing otter board hydrodynamic performances in wind tunnel facilities. Ocean Engineering, 104: 52-62. http://dx.doi.org/10.1016/j.oceaneng.2015.04.064

Meyler, L. (2008) Simulation of Net Structures Hydrodynamic Fields, Modelling and Simulation. In: P. Giuseppe and C. Giuliano. (Eds.). ISBN: 978-3-902613-25-7, Intech. http://www.intechopen.com/books/modelling_and_simul ation/simulation_of_net_structures_hydrodynamic_fields

Meyler, L. (1995) Flow speed investigation on schematized net constructions, Report No 94/71, IFREMER, France, $95 \mathrm{pp}$

Muchtar, H., Nishinokubi and Nakasai, K. (1973) Study of the six-seam trawl - II. Bulletin Faculty of Fishery, Nagasaki University. Japan, 36: 93-101.

Nomura, M. (1977) Shrimp trawl fishing experiment. SEAFDEC, Fishing technique, JICA publication, pp. 105-125.

Nomura M. (1989) Fishing Techniques (2). Regional training course in coastal fisheries development. JICA publication, pp. 52-58.

Nomura, M., Mori, K., Tawara, Y., Osawa, Y., Shimada, Y., and Senga, K. (1977) Factors of trawl net 


\section{Conclusion}

In perspective of the fundamental suggestions on the gear efficiency, the side net of shrimp trawl should first be properly reconstructed to have better net shape and increase the net height opening with the appropriate hanging ratio, for example, by inserting triangle nets between the side net and baiting. The modified trawl net design can be seen in Figure 6. The length of nets will be afforded to the lacing lines to increase the height of net opening by better distributing the towing forces which had previously been concentrated on the head rope and ground rope. The increasing of net height opening was also expected to increase the catches production of both shrimp and fish especially in the same months of fishing seasons, and local fishermen are more likely to use new techniques if they perceive realized benefits. More comprehensive data on shrimp behavior during trawling is also strongly recommended.

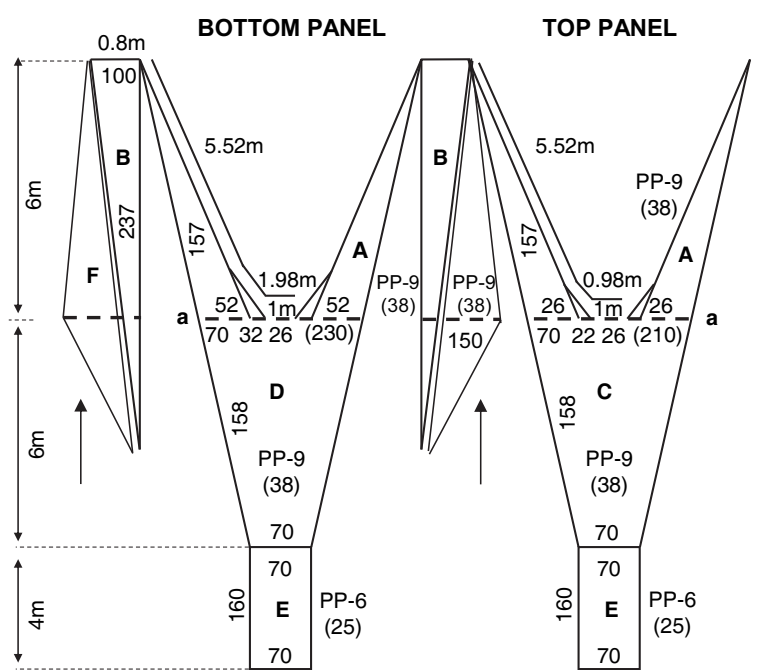

Figure 5. Design modification of full scale bottom trawl net design where the triangle nets $(\mathbf{F})$ will be inserted between the side nets (B) and baiting (C) to improve the gear efficiency of the net, as well as to catch simultaneously fish and shrimp in the same months of fishing seasons

\section{Acknowledgment}

This research funded by the Ministry of Education, Culture, Sports, Science and Technology of Japan. We are much obliged to Prof Shigeru Fuwa, Dr. Keigo Ebata and Mr. Masataka MARUGI from the Faculty of Fishery, Kagoshima University Japan. Thankfulness to $\mathrm{Mr}$ Syamsul Wahid, $\mathrm{Mr}$ Ahmad Rizani and Mr. Eddy Zainuddin who have supported this study. We also wish to acknowledge to anonymous reviewers for their valuable comments.

\section{References}

Ahmadi, Fuwa, S., Ebata, K. and Budiman, J. (2005) Comparative Study on the Performance of Lampara Dasar (Indonesian Traditional Bottom Trawls). Memoirs of Faculty of Fishery, Kagoshima University, Japan, 54: 4556.

Balash, C., Sterling, D., Binns, J., Thomas G. and Bose, N. (2011) The effect of mesh orientation on netting drag and its application to innovative prawn trawl design. Fisheries Research Development Corporation. Project \#2011/209. 14 pp

Balash, C. and Sterling, D. (2012) Prawn trawl drag due to material properties - An investigation of the potential for drag reduction. In: The $2^{\text {nd }}$ International Symposium: Fishing Vessel Energy Efficiency, Vigo, Spain, May 2012.

Bayse, S. M., Pol, M. V. and He, P. (2016) Fish and squid behaviour at the mouth of a drop-chain trawl: factors contributing to capture or escape. ICES Journal of Marine Sciences, 73(6): 1545-1556.

BPS-Statistic of Kotabaru Regency. (2015) Kotabaru Regency in Figure 2015. 393 pp. https://kotabarukab.bps.go.id/webbeta/website/pdf pub likasi/Kotabaru-Dalam-Angka-2015.pdf

Broadhurst, M. K., Sterling, D. J. and Millar, R. B. (2014) Configuring the mesh size, side taper and wing depth of Penaeid trawls to reduce environmental impacts. PLoS ONE 9(6): e99434. doi:10.1371/journal.pone.0099434

Chin, C., May, R. and Connell, H. (2000) A numerical model of a towed cable-body system. ANZIAM Journal, 42(E): C362-C384 
trawler is exposed to side currents and/or wind, the effective resistance to forward motion is increased; rudder drag increases due to the application of rudder to produce the necessary angle of leeway and angled flow onto the hull to resist the side loads, hull drag is increased because it is travelling at an angle of attack (leeway) and lastly, because of the misalignment of the flow into the propeller, the thrust force is slightly reduced. Meanwhile Harrington et al. (1988) reported that one potentially important variable is the area of netting in the trawl wings (typically controlled by depth or the number of meshes in the transverse direction), which varies considerably among designs. Because the headline height of many penaeid trawls is largely determined by the height of the otter boards, unlike fish trawls, varying wing depth will not necessarily affect the vertical trawl opening, but concomitant differences in associated twine area should impact on drag and potentially selectivity.

In the flume tank, at lower towing speeds, the net shape is relatively changeable corresponding to the flow speed given and tends to hold own shape constantly at higher towing speeds. It is clearly observed that water flow velocity and pressure distribution around trawl can alternate mesh shape from diamond to parallelogram. Such visual observation was consistently found at various wing tips distances. According to Meyler (2008) the flow around a net surface has some features, one of them, is a net structure shape creation, i.e. the structure "chooses" itself such shape under the flow that a pressure difference on its surface has a constant value.
Researchers encountered problems in experiments to measure the change in velocities everywhere inside a net structure because of a difficulty to penetrate with a log through meshes due to their small size especially in cod-end. Therefore, a method of flow velocities studies on schematized net structures (SNS) was proposed (Meyler, 1995). Taking into account that such constructions as the trawl cod-end has an axisymmetric shape, distributions of flow parameters (velocities and pressures) inside and around the structure have the axisymmetric character as well. Furthermore Meyler (2008) illustrated the flow into rear net cylindrical part of the cod-end with a "catch" simulation (see Figure 5). The fish simulation was created with "solid" bodies given as cylindrical cross sections. It is seen that "the catch" gives a backwater flow and, so called, "locking" effect. It permits to have a possibility for a fish escape from the trawl or make "meshing" of the codend that is to block meshes of the net. The distribution of the velocities is changed. The velocity decrease is stronger in the rear part of the model and just in front of the "catch" velocities are equal to zero.

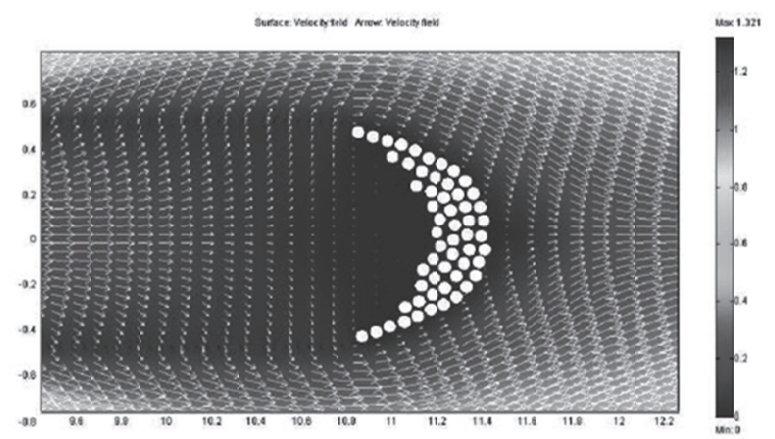

Figure 4. Speed distribution with a "catch" imitation in a codend (Meyler, 2008) 
panel. This is attributable to the net structure itself associated with low value of $H / a$ ratio since there is no square part in the net body construction.

Table 5. Descriptive statistics of constant $(a)$ and exponent $(b)$ obtained from the linear equations of the estimated parameters.

\begin{tabular}{|c|c|c|c|c|c|c|c|c|c|c|c|}
\hline \multirow{3}{*}{$\begin{array}{l}\text { Parameters } \\
\text { measured }\end{array}$} & \multirow{3}{*}{$\begin{array}{l}\text { Linear } \\
\text { Equations }\end{array}$} & \multicolumn{10}{|c|}{ Wing tips distance (\% of head rope length) } \\
\hline & & \multicolumn{2}{|c|}{$\begin{array}{l}80 \mathrm{~cm} \\
(46 \%)\end{array}$} & \multicolumn{2}{|c|}{$\begin{array}{l}90 \mathrm{~cm} \\
(51 \%)\end{array}$} & \multicolumn{2}{|c|}{$\begin{array}{l}100 \mathrm{~cm} \\
(57 \%)\end{array}$} & \multicolumn{2}{|c|}{$\begin{array}{l}105 \mathrm{~cm} \\
(60 \%)\end{array}$} & \multicolumn{2}{|c|}{$\begin{array}{l}115 \mathrm{~cm} \\
(66 \%)\end{array}$} \\
\hline & & $a$ & $B$ & $a$ & $b$ & $a$ & $b$ & $a$ & $b$ & $a$ & $b$ \\
\hline Net height & $H=a V^{b}$ & 251.95 & -0.73 & 349.79 & -0.82 & 394.79 & -0.87 & 178.91 & -0.67 & 312.71 & -0.84 \\
\hline Projective area & $P=a V^{b}$ & 104.02 & -0.60 & 154.6 & -0.69 & 197.37 & -0.76 & 103.21 & -0.55 & 222.43 & -0.76 \\
\hline Filtering volume & $F V=a V^{b}$ & 30.14 & 0.23 & 32.05 & 0.31 & 31.44 & 0.25 & 38.14 & 0.45 & 34.60 & 0.24 \\
\hline Total net resistance & $R=a V^{b}$ & 0.03 & 1.30 & 0.02 & 1.37 & 0.04 & 1.24 & 0.01 & 1.49 & 0.02 & 1.37 \\
\hline $\begin{array}{l}\text { Ratio of net height } \\
\text { to circumference }\end{array}$ & $H / a=a V^{b}$ & 1.05 & -0.73 & 1.45 & -0.82 & 1.64 & -0.87 & 0.74 & -0.68 & 1.30 & -0.84 \\
\hline
\end{tabular}

In the flume tank, operational nature of net mouth area of the trawl model is alterable/ variably following magnitude of towing speed and the mass of water encountering the net is proportional to net mouth area. In actual fishing practices, the mass of catch encountering the gear is also proportional with net mouth area of the trawl, and that the amount of fish caught by trawl is the intersection of mouth trawl area and fish distribution (Khaled et al., 2012). According to Walsh (1996) the efficiency of the trawl is defined as the area between the wing ends and the center of the footgear. Meanwhile Fridman (1986) stated that trawl efficiency is the ratio of the number of fish which is caught and retained by the net to the number of fish in the trawl path. During experiment, each wing-end spread was fixed at certain distances. This assumes that swept area on each treatment is constant. In the field, however, wing spread may change and swept area become narrower depending on the speed of boat and otter board spreads. Principally trawls had flexible structures which change shape under various conditions. Walsh (1996) asserted that the shape of the trawl in deep water is more collapse than in shallower water due to differences in trawl door spreads.

During experiment, the net mouth opening was fixed at the distance of $80-115 \mathrm{~cm}$ or 46$66 \%$ of head rope length with relative constant angle of attack at each distance. The height of net mouth opening depends on towing speed and distance between both wing tips. This phenomenon can be seen clearly when towing speed and wing tips distance increased, the height of net became decreased. In the field, the change in ship direction is not only affecting the wing-end spread and otter board position but also will increase the netting drag force. Sterling (2009) stated that when a 
wing-end spread of $8.4 \mathrm{~m}$ and $50 \mathrm{~m}$ warp length. This ratio is about two time higher than Italian bottom trawls i.e. 0.09 (Fiorentini et al., 2004). It was further explained that the wingend spread was strongly affected by the warp and sweep length. During the hauls made where the warp length was $150 \mathrm{~m}$ and sweep was $203 \mathrm{~m}$, the wing-end spread reached value less than $13 \mathrm{~m}$, in contrast with approximately $18 \mathrm{~m}$ measured when the warp paid out was $350 \mathrm{~m}$ and sweep was $81 \mathrm{~m}$ (Fiorentini et al., 2004). On other words, the longer the warp length the wider the wing-end spread, whereas the longer the sweep length the smaller the wing-end spread.

\section{Trawl Dimensions}

For catching swimming fish, Nomura (1977) suggested that the trawl net should have a long head rope in order to take in a big volume of water with a high opening of net mouth. A long net body is also necessary to prevent the trapped fish from escaping despite the low towing speed. While for catching shrimp, the trawl net should have a wide but flat net mouth, and it is not necessary to have a long body. Nomura (1989) reported that normally the trawl net height opening will be a certain percentage of $a$ value, for example: $5 \%$ for two-seam trawl net, $10 \%$ for big stern trawl, 4-8 seam, and 15\% for two-boat type trawl. The net circumference is often used as a main basic of comparison for other trawl dimensions. The difference can be compared by the non-dimension number of the ratio of total length of net to the net circumference $(T L / a)$. Figures $1 \mathrm{~A}$ and B clearly showed that the $T L / a$ ratio of the current bottom trawl is much smaller than bottom trawls from other geographical areas. However, it is higher than other bottom trawls in term of the ratio of body length to the net circumference $(B L / a)$ the middle-level (Figure 1C), and be in the middle-level in view of the ratio of wing length to the net circumference $(W L / a)$ as shown in Figure 1D. For the purpose of increasing the net height opening, Nomura
(1989) suggested that the maximum stretched circumference of net should have a big value; in particular the first essential is to increase the width of the side net. In the present study, the $T L / a$ ratio obtained were 0.83 . The function of the side net which is constructed with a 100 meshes in $0.8 \mathrm{~m}$ wide is seemingly not able to raise the value of $T L / a$ ratio; moreover the net has no square part of the net body. It is most likely to cause an effect on the net shape and the net height opening. Even though for the purpose of catching shrimp, the net height is not necessary, however, in this area of study, the height of net mouth is still considered to be important thing because of having correlation to the shape of gear constructions and performance of bottom trawl net under different trawling conditions.

\section{Gear performance}

In the flume tank, the water flow velocities and pressures distribution both around and in trawl yield the forces acting on each part of the trawl system that may influence the shape, drag and behavior of net structure as well as tension and loads in its twines and ropes. According to Meyler (2008), the flow velocities and pressures particularly in the cod-end, have a very significant influence on the fish motion process. The netting is responsible for on average $2 / 3$ of the total water resistance from the boat and gear during trawling. Various techniques have been developed by researchers and fishermen to estimate twine thickness, mesh and knot size required for reducing the drag force (Balash and Sterling, 2012). In the present study, the exponent values of total net resistance ranged from 1.24 to $1.49(1.37 \pm 0.10$, mean $\pm \mathrm{SD})$ indicating that the shape of net body under towing condition should be refined (Table 5). Tauti (1934) suggested that indication of the best condition of net shape deformation if the value of exponent is 2.0. The estimated value of net resistance seems to be small corresponding to the net height and the attack angles of net 
was not suitable for making model scale. For this reason, nylon Polyamide (PA) is preferable. In the full scale, the net body was constructed with $38 \mathrm{~mm}$ stretched mesh with twine diameter $1.08 \mathrm{~mm}$ (PP 170D/9) and 25 $\mathrm{mm}$ stretched mesh with twine diameter 0.98 $\mathrm{mm}$ (PP 170D/6) for the cod end. Meanwhile in the model scale, the nets all were constructed with $15 \mathrm{~mm}$ stretched mesh with twine diameter $0.42 \mathrm{~mm}$ (PA 210D/9). It is generally accepted that the tow resistance tests in the flume tank indicated that large drag reductions occur commensurate with reduced twine diameter. A more recent innovation to significantly reduce drag was high-strength Dyneema and spectra netting materials that allow the use of thinner twine compared to traditional materials. Small diameter Dyneema and spectra netting twine are of similar breaking strength to traditional material, but the thinner twine results in decreased drag. However, a disadvantage of the new material is that it is significantly more expensive than the conventional netting, which makes trawl operators reluctant to widely implement the innovation. In addition, Dyneema twine has very low bending stiffness, which produces operational difficulties due to fouling during trawl deployment and hauling (Balash and Sterling, 2012). The Spectra and Euroline materials strength is about the same as polyethylene, but the mesh strength of the two Dyneema materials (Dynex and Ultracross) are about 3 times higher (Balash and Sterling, 2012).

\section{The ratio of head rope to ground rope}

In the present study, the ratio of head rope to ground rope is 0.88 , which is slightly higher than suggested by Nomura et al. (1977) and Khaled et al. (2012) i.e. 0.87 and 0.80 respectively. In this study, the ground rope is 2 $\mathrm{m}$ behind head rope, and considered sufficient for catching shrimp with the height of net ranged of 0.68-1.32 m. In practical, Main and Sangster (1985) reported that the Nephrops norvegicus during trawling did not swim higher than $1 \mathrm{~m}$ from seabed and enter the net only through the width of the bosom groundline. One of the most important factors to enhance the performance of a trawl net is the effect of floats and sinkers (ground chain) during towing operation. The buoyancy force on the head rope will hold the net open vertically while the sinking force of the ground rope must be having good touch connection power to the sea bottom. Excess of sinking force will make the ground rope to dig in the ground. Consequently, this could lead to a bigger towing resistance. Otherwise, if the net has excess of buoyancy force, the horizontal spreads of net will decrease and the capacity of ground rope pressing the bottom will be diminished. The rope for managing net and that for holding the buoys and sinkers have two kinds of influences upon the form of net, one is due to that they have the unchangeable length and the other due to that they have the apparent weight in water and that they are under the resistance of water. The whole hydrodynamic force amounts to the superposition of the forces applied to each cylindrical rigid element. Mesh bars may be considered as hydrodynamically independent relative to water flow. According to Fiorentini et al. (2004) the introduction of drop meshes in the wing sections of the upper panel, will give less restriction to the headline than an allbar cut.

\section{The ratio of wing-end spread to the warp length}

Another issue related to this work is the ratio of wing-end spread to the warp length. In the full scale, the said ratio was 0.17 determined at towing speed of 3 knots with 
significantly difference in the $H / a$ ratio among the five wing-end spreads $\left(\chi^{2}=17.266, \mathrm{df}=4\right.$, $\mathrm{p}<0.05)$. The $H / a$ ratio at $46 \%(80 \mathrm{~cm})$ of HR length was significantly higher than that at $66 \%(115 \mathrm{~cm})(\mathrm{t}=6.674, \mathrm{df}=8, \mathrm{p}<0.001)$. At a towing speed of $96 \mathrm{~cm} / \mathrm{s}$ ( $3 \mathrm{knots}$ ), the $H / a$ ratio was $0.034 \pm 0.004$ or $3.4 \%$ of net circumference and getting lower at higher towing speeds. The highest $H / a$ ratio was 0.042 with wing tips distance of $80 \mathrm{~cm}(6.4 \mathrm{~m}$, $46 \%$ in full scale) and the lowest one was 0.029 with wing tips distance of $115 \mathrm{~cm}(9.2$ $\mathrm{m}, 66 \%$ in full scale). The value of $H / a$ ratio obtained was low because there was no square part in the net body construction. The square is a rectangular sheet of netting. The section of netting fitted between the top body (baiting) and the two top wings so that it partially overhangs the ground rope. It is really this part of the trawl net which to a great degree governs the way the rest of the net can be shaped. At the same buoyancy of floats, the bigger the net circumference the higher the net opening. The $H / a$ ratio was gradually decreased with increasing the towing speed to a definite speed at which the reduction rate tended to be zero and the value of the ratio becomes stable. This speed may be slower when a distance between both wing tips is wide, because the net webbing near net mouth expanded to sideways, a little expansive power from net webbing itself will be raised by increasing towing speed. It will be balanced to the buoyancy of float function and maintain some heights of net mouth.

\section{Discussion}

\section{Trawl model construction}

It is also necessary to understand that before constructing the model scale net, a decision on a reducing scale should be determined carefully in order that the size of net can be accommodated in the water circular tank and the whole net body can be seen through the observation window without any difficulties. In making the model scale, a similar construction as the original full scale has to be adopted in all parts. In other words, designing and constructing a scale model is to get some indications of what the full scale trawl or prototype will look like prior to construction based on available room. It is found to be more convenient to use stationary models and let the water flow through and around them rather than actually towing the models through stagnant water. However, it is difficult to achieve a dynamic similarity between the prototype and the full-scale gear (Prat et al., 2008).

When constructing the model trawl, it is in most cases impossible to reduce the mesh to the size required by the length scale. However, a larger mesh size may be used in the model if the influence of this mesh size is compensated with the use of another twine diameter so that the hydrodynamic drag forces acting on any section of the prototype trawl and the corresponding section of the model have the correct force scale (Christensen, 1974). The twine material should be carefully chosen in order to have a flexibility of netting structure for ascertaining dynamic similarity on trawl net model (Hu et al., 2001). Stiff netting would not give a smooth net shape. In the present study, Polypropylene (PP) twine was used for making full scale trawl, but it 


\begin{tabular}{lrrrrr} 
Total net resistance $\left(10^{2} \mathrm{~g}\right)$ & 9.28 & 10.61 & 11.77 & 13.46 & 14.46 \\
Attack angle at head rope $\left(^{\circ}\right)$ & 24 & 22 & 24 & 24 & 24 \\
\hline Experiment-5 & \multicolumn{5}{r}{ Wing tips distance $115 \mathrm{~cm}$ (66\% of HR length) } \\
Towing speed $(\mathrm{cm} / \mathrm{s})$ & 77 & 83 & 89 & 96 & 102 \\
Height of net mouth $(\mathrm{cm})$ & 8.1 & 7.6 & 7.0 & 7.0 & 6.9 \\
Ratio of net height/circumference $(H / a)$ & 0.034 & 0.032 & 0.029 & 0.029 & 0.029 \\
Projective area of net mouth $\left(10^{2} \mathrm{~cm}^{2}\right)$ & 7.97 & 7.63 & 7.11 & 7.14 & 6.68 \\
Water filtering volume $\left(10^{3} \mathrm{~m}^{3}\right)$ & 35.43 & 36.77 & 36.91 & 39.64 & 39.56 \\
Total net resistance $\left(10^{2} \mathrm{~g}\right)$ & 9.30 & 10.20 & 11.33 & 13.07 & 13.75 \\
Attack angle at head rope $\left(^{\circ}\right)$ & 27 & 29 & 29 & 29 & 29 \\
\hline
\end{tabular}

\section{Total net resistance}

There was no significantly difference in total net resistance among the five wing-end spreads $\left(\chi^{2}=2.794, \mathrm{df}=4, \mathrm{p}>0.05\right)$ but it was statistically significant difference among the five towing speeds applied $(\mathrm{t}=20.500, \mathrm{df}=4$, $\mathrm{p}<0.001)$. Total net resistance at the highest towing speed was considerably higher than that at the lowest speed $(\mathrm{t}=-9.346, \mathrm{df}=8$, $\mathrm{p}<0.001)$. At a towing speed of $96 \mathrm{~cm} \mathrm{~s}^{-1}$ (3 knots), total net resistances ranged from $11.07 \times 10^{2}$ to $13.46 \times 10^{2} \mathrm{~g}$ (from 8.86 to 10.77 $\mathrm{kg}$ in full scale). The highest total net resistance was $14.46 \times 10^{2} \mathrm{~g}$ with wing tips distance of $105 \mathrm{~cm}$, and the lowest one was $11.73 \times 10^{2} \mathrm{~g}$ at the distance of $100 \mathrm{~cm}$. Total net resistance increases proportionally to towing speeds. When the towing speed increases intensively, it will bring a big volume of water entering into the net, the resistance of net increases remarkably, and in consequence, the force to make the net wide increases. Total net resistance is parallel to the flow in line with the cod end, but tension is not parallel, it corresponds more to the towing line and attack angle of warp. Total net resistance, which measured on the head rope, was larger than the ground rope. During experiments, wing tips distances slightly expanded from its initial position i.e. about $2.0-4.2 \mathrm{~cm}$ because of a large towing resistance toward the net.

It can be understood that trawl net when exerted by water forces, distribution of the towing forces more concentrated on the head rope, so that the upper part of net has tendency to lessen its room and in consequence, the angle of incidence becomes smaller than the lower one. The attack angle was much influenced by wing tips distances; the wider of wing tips distance the bigger the attack angle of warp (Table 4). Dealing with the increasing of towing speed, it can be generally said that some of the attack angles tend to have its own values constantly at various wing tips distances.

\section{The gear efficiency of the net}

We already obtained the results of measurements on the net height in the flume tank; however, the gear efficiency cannot be determined directly by these values. We applied a non-dimension number of the ratio of net height $(H)$ to the net circumference $(a)$ to determine the gear efficiency of the net, since this factor is closely related to the gear construction and performance of trawl net. In the present study, the $H / a$ ratio ranged from 0.029 to 0.038 (Table 4). There was 
water filtering volume. It is clearly confirmed that the higher the towing speed the larger the water filtering volume. In this trial, the largest water filtering volume was $48.36 \times 10^{3} \mathrm{~m}^{3}$ with wing tips distance of $105 \mathrm{~cm}$ at $102 \mathrm{~cm} \mathrm{~s}^{-1}$ (3.2 knots) towing speed, and the smallest one was $32.04 \times 10^{3} \mathrm{~m}^{3}$ with wing tips distance of
$100 \mathrm{~cm}$ at $77 \mathrm{~cm} \mathrm{~s}^{-1}$ (2.4 knots) towing speed. Trawl net with large water filtering volume is more efficient than small one because it is assumed that in one unit time of towing operation, the net will filter more fish and shrimp.

Table 4. Descriptive parameters and measurement results of a bottom trawl model scale.

\begin{tabular}{|c|c|c|c|c|c|}
\hline Experiment-1 & \multicolumn{5}{|c|}{ Wing tips distance $80 \mathrm{~cm}$ (46\% of HR length) } \\
\hline Towing speed $(\mathrm{cm} / \mathrm{s})$ & 77 & 83 & 89 & 96 & 102 \\
\hline Height of net mouth $(\mathrm{cm})$ & 10.2 & 10.0 & 9.5 & 9.2 & 9.1 \\
\hline Ratio of net height/circumference $(H / a)$ & 0.042 & 0.042 & 0.039 & 0.038 & 0.038 \\
\hline Projective area of net mouth $\left(10^{2} \mathrm{~cm}^{2}\right)$ & 7.38 & 7.09 & 6.90 & 6.84 & 6.80 \\
\hline Water filtering volume $\left(10^{3} \mathrm{~m}^{3}\right)$ & 32.82 & 34.17 & 35.81 & 38.02 & 40.27 \\
\hline Total net resistance $\left(10^{2} \mathrm{~g}\right)$ & 9.12 & 10.29 & 11.34 & 12.72 & 13.49 \\
\hline Attack angle at head rope $\left(^{\circ}\right)$ & 16 & 14 & 16 & 16 & 16 \\
\hline Experiment-2 & \multicolumn{5}{|c|}{ Wing tips distance $90 \mathrm{~cm}(51 \%$ of HR length) } \\
\hline Towing speed $(\mathrm{cm} / \mathrm{s})$ & 77 & 83 & 89 & 96 & 102 \\
\hline Height of net mouth $(\mathrm{cm})$ & 9.3 & 9.1 & 8.7 & 8.3 & 8.2 \\
\hline Ratio of net height/circumference $(H / a)$ & 0.039 & 0.038 & 0.036 & 0.034 & 0.034 \\
\hline Projective area of net mouth $\left(10^{2} \mathrm{~cm}^{2}\right)$ & 7.42 & 7.17 & 6.78 & 6.61 & 6.64 \\
\hline Water filtering volume $\left(10^{3} \mathrm{~m}^{3}\right)$ & 33.00 & 34.55 & 35.16 & 36.72 & 39.32 \\
\hline Total net resistance $\left(10^{2} \mathrm{~g}\right)$ & 8.99 & 10.04 & 11.33 & 12.69 & 13.65 \\
\hline Attack angle at head rope $\left(^{\circ}\right)$ & 18 & 18 & 18 & 18 & 18 \\
\hline Experiment-3 & \multicolumn{5}{|c|}{ Wing tips distance $100 \mathrm{~cm}(57 \%$ of HR length) } \\
\hline Towing speed $(\mathrm{cm} / \mathrm{s})$ & 77 & 83 & 89 & 96 & 102 \\
\hline Height of net mouth $(\mathrm{cm})$ & 8.9 & 8.0 & 7.7 & 7.5 & 7.3 \\
\hline Ratio of net height/circumference $(H / a)$ & 0.037 & 0.033 & 0.032 & 0.031 & 0.030 \\
\hline Projective area of net mouth $\left(10^{2} \mathrm{~cm}^{2}\right)$ & 7.21 & 6.88 & 6.67 & 6.35 & 6.14 \\
\hline Water filtering volume $\left(10^{3} \mathrm{~m}^{3}\right)$ & 32.04 & 33.13 & 34.60 & 35.27 & 36.37 \\
\hline Total net resistance $\left(10^{2} \mathrm{~g}\right)$ & 8.87 & 9.98 & 9.82 & 11.07 & 11.73 \\
\hline Attack angle at head rope $\left(^{\circ}\right)$ & 22 & 20 & 20 & 22 & 22 \\
\hline Experiment-4 & \multicolumn{5}{|c|}{ Wing tips distance $105 \mathrm{~cm}(60 \%$ of HR length) } \\
\hline Towing speed $(\mathrm{cm} / \mathrm{s})$ & 77 & 83 & 89 & 96 & 102 \\
\hline Height of net mouth $(\mathrm{cm})$ & 9.5 & 9.3 & 8.9 & 8.6 & 8.4 \\
\hline Ratio of net height/circumference $(H / a)$ & 0.039 & 0.039 & 0.037 & 0.036 & 0.035 \\
\hline Projective area of net mouth $\left(10^{2} \mathrm{~cm}^{2}\right)$ & 9.12 & 8.94 & 8.71 & 8.44 & 8.16 \\
\hline Water filtering volume $\left(10^{3} \mathrm{~m}^{3}\right)$ & 40.55 & 43.05 & 45.17 & 46.90 & 48.36 \\
\hline
\end{tabular}




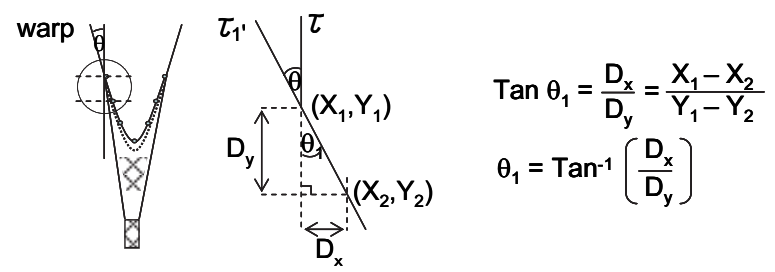

Figure 3. Measurement of warp tension and angles of trawl net model

For statistical analysis, the t-test was employed to compare the values between two variable tested. Kruskal-Wallis test was used to examine differences among the treatments. Multiple comparison tests were conducted to see which values differed among the treatments. All tests were analyzed at the 0.05 level of significance using SPSS-16.0 software.

\section{Results}

The output results from the measurement and calculation of the experimental model scale are presented in Table 4, and are described as follows:

\section{Height of net mouth}

The results showed that the height of net mouth decreased gradually with increasing the towing speed and distance between both wing tips. There was statistically significant difference in the net height among the five wing-end spreads $\left(\chi^{2}=17.911, \mathrm{df}=4, \mathrm{p}<0.001\right)$. The net height at $46 \%(80 \mathrm{~cm})$ of HR length was considerably higher than that of $66 \%$ (115 $\mathrm{cm})(\mathrm{t}=7.196, \mathrm{df}=8, \mathrm{p}<0.001)$. At towing speed $96 \mathrm{~cm} \mathrm{~s}^{-1}$ ( 3 knots), the net height at different wing tips distances varied from 7.0 to $9.2 \mathrm{~cm}$ (from 0.56 to $0.74 \mathrm{~m}$ in full scale). The highest net mouth opening height was $10.2 \mathrm{~cm}(0.82 \mathrm{~m}$ in full scale $)$ with wing tips distance of $77 \mathrm{~cm}(6.4 \mathrm{~m}, 46 \%$ of HR length in full scale) at towing speed of $77 \mathrm{~cm} \mathrm{~s}^{-1}(2.4$ knots), and the lowest one was $6.9 \mathrm{~cm}(0.55 \mathrm{~m}$ in full scale) with wing tips distance of 115 $\mathrm{cm}(9.2 \mathrm{~m}, 66 \%$ of HR length in full scale) at towing speed of $102 \mathrm{~cm} \mathrm{~s}^{-1}$ (3.2 knots).

\section{Projective area of net mouth}

The largest projective area was $9.12 \times 10^{2}$ $\mathrm{cm}^{2}\left(1.02 \mathrm{~m}^{2}\right.$ in full scale $)$ at the distance 105 $\mathrm{cm}(8.4 \mathrm{~m}, 60 \%$ of HR length in full scale) and the smallest one was $6.14 \times 10^{2} \mathrm{~cm}^{2}(0.66$ $\mathrm{m}^{2}$ in full scale) at the distance of $100 \mathrm{~cm}(8.0$ $\mathrm{m}, 57 \%$ of HR length in full scale). There was statistically significant difference in projective area of net mouth among the five wing-end spreads $\quad\left(\chi^{2}=14.393, \quad \mathrm{df}=4, \quad \mathrm{p}<0.05\right)$. The projective area of net mouth at $46 \%(80 \mathrm{~cm})$ of HR length was significantly higher than that at $60 \% \quad(105 \mathrm{~cm}) \quad(\mathrm{t}=-8.268, \mathrm{df}=8$, $\mathrm{p}<0.001)$. At towing speed of $96 \mathrm{~cm} \mathrm{~s}^{-1}$ (3 knots), the projective areas of net mouth ranged from $6.35 \times 10^{2}$ to $8.44 \times 10^{2} \mathrm{~cm}^{2}(0.68$ $0.96 \mathrm{~m}^{2}$ in full scale). The projective area of net mouth decreases when towing speed increases.

\section{Water filtering volume}

The calculated data showed that there was statistically significant difference in water filtering volume among the five wing-end spreads $\left(\chi^{2}=15.102, \mathrm{df}=4, \mathrm{p}<0.05\right)$. Water filtering volume at $46 \%(80 \mathrm{~cm})$ of HR length was considerably higher than that at $60 \%$ (105 $\mathrm{cm}) \quad(\mathrm{t}=-4.467, \quad \mathrm{df}=8, \quad \mathrm{p}<0.05) . \quad$ This is relatively proportional to the increasing of projective area of net mouth and the intensity of towing speeds. Water filtering volume at a towing speed of $96 \mathrm{~cm} \mathrm{~s}^{-1}$ (3 knots) varied from $32.04 \times 10^{3}$ to $40.55 \times 10^{3} \mathrm{~m}^{3}$. The changeover scale model wing tips distances from 100 to $115 \mathrm{~cm}$ have produced more 
made of glass, a window situated at the center of the channel make it possible to take measurements and photographs. The experimental conditions can also be observed from the top and side views. The experimental model net was placed on the floor of observation channel under ordinary current. Flow speeds used in these experiments included the towing speed used in the actual fishing i.e. 3 knots $\left(96 \mathrm{~cm} \mathrm{~s}^{-1}\right.$ in model scale). In this study, the flow speeds of model were $77,83,89,96$, and $102 \mathrm{~cm} \mathrm{~s}^{-1}$ (corresponding to the full-scale range of 2.4, 2.6, 2.8, 3.0, and 3.2 knots). Wing tips distances were set at $46 \%(80 \mathrm{~cm}), 51 \%(90 \mathrm{~cm}), 57 \%(100 \mathrm{~cm})$, $60 \%(105 \mathrm{~cm})$ and $66 \%(115 \mathrm{~cm})$ of HR length respectively (corresponding to full-scale wingend spreads of 6.4, 7.2, 8.0, 8.4 and $9.2 \mathrm{~m}$ ). Actually, measurements of wing tips distance have also been tried during trawling operation in Kotabaru but unsatisfied due to inappropriate instrument used.

TOP VIEW

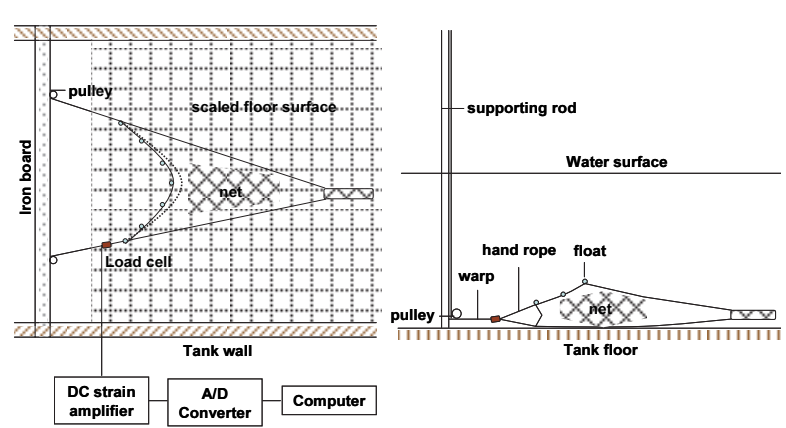

Figure 2 The schematics of experiment that shows the facilities and apparatus used in the experiment

In a flume tank, wing tips distance was adjusted to a desired distance by simply placing the supporting rod on the iron board which holds the towing line (warp) through the moveable pulley which connected to the hand ropes of wing tips and load cell. The height of net mouth was measured directly by using a laser point (laser beam sight level 230) and millimeter bar through the observation window. The height of net mouth is defined as vertical distance from the head rope to the ground rope at the central point of head rope. To make light of measurement, 7 marked floats along the head rope were fixed to be the measured points of the net mouth height. The distances of each marked float were also measured (represented by the $X$ and $Y$ coordinates).

The projective area of net mouth, water filtering volume and total net resistance were expressed with the following equations:

$$
\begin{aligned}
& \mathbf{P}=\Sigma(\mathbf{H} \times \mathbf{D}) \ldots \ldots \ldots \ldots \ldots \\
& \mathbf{F V}=\mathbf{P} \times \mathbf{V} \times \mathbf{T} \ldots \ldots \ldots \ldots \\
& \mathbf{R}=\boldsymbol{\tau}_{\mathbf{1}} \operatorname{Cos} \theta_{1}+\boldsymbol{\tau}_{\mathbf{2}} \operatorname{Cos} \theta_{2}
\end{aligned}
$$

Where: $\mathrm{P}=$ Projective area of net mouth $\left(\mathrm{cm}^{2}\right)$, $\mathrm{H}=$ height of net $(\mathrm{cm}), \mathrm{D}=$ distance of wing tips $(\mathrm{cm}), \mathrm{FV}=$ water filtering volume $\left(\mathrm{m}^{3}\right), \mathrm{V}$ $=$ towing speed $\left(\mathrm{cm} \mathrm{s}^{-1}\right), \mathrm{R}=$ total net resistance ( $\mathrm{g}), \mathrm{T}=$ time (sec), $\boldsymbol{\tau}_{1}$ and $\boldsymbol{\tau}_{2}=$ tension of warp and $\theta_{1}$ and $\theta_{2}=$ attack angle of warp $\left(^{\circ}\right)$. Measurement of warp tension and angles of trawl model is illustrated in Figure 4.

Tension of line was measured indirectly by using three components such as load cell, DC strain amplifier and Analog Digital Converter, which connected and recorded into the personal computer (PC) and also through the instrumental calibration. The ratio of net height to the net circumference was presented corresponding to the gear construction and performance of trawl at various wing tips distances and towing speed condition. 


$$
\begin{aligned}
& \text { The warp length } \\
& \text { Trawling time } \\
& \text { Hauling methods } \\
& \text { Number of crew } \\
& \text { Number of Fishing day } \\
& \text { Sea-bed condition }
\end{aligned}
$$

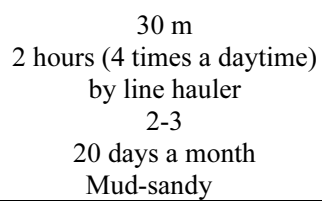

$30 \mathrm{~m}$

2 hours (4 times a daytime)

by line hauler

2-3

20 days a month

Mud-sandy

The main dimensions of the experimental model scale are as follows: the reducing ratio was $1 / 8$, the ratio of flow speed was 0.62 and the ratio of twine diameters to the ratio of mesh sizes (bar lengths) was 0.028 (Table 3). The model nets were constructed with Polyamide twine of 210 denier 9 ply, $15 \mathrm{~mm}$ stretched mesh with twine diameter $0.42 \mathrm{~mm}$. Model net was built and rigged with a $1.75 \mathrm{~m}$ head rope and a $2 \mathrm{~m}$ ground rope of Polyethylene with rope diameter $1.125 \mathrm{~mm}$ (Figure 2). The ratio of the head rope to the ground rope equals 0.88 . Total buoyancy of floats was $23.67 \mathrm{~g}$, composed of 26 floats along the head rope holding the net open vertically. Total sinkers weight in air was $74.49 \mathrm{~g}$ containing $160 \mathrm{pcs}$ of leads that were attached to the ground rope in each $2.5 \mathrm{~cm}$ long with $80 \underset{\text { model scale }}{\text { int scale }}$
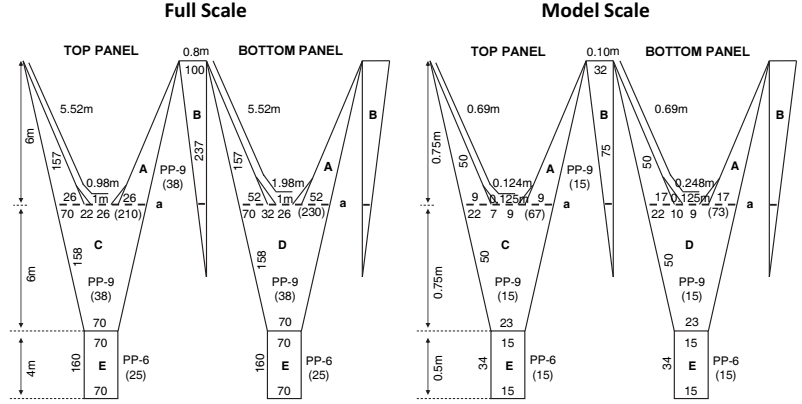

Figure 1. Full scale net and model scale net plan at $1 / 8$ scale of

\begin{tabular}{|c|c|c|c|c|c|c|c|c|c|}
\hline Type of net & $\begin{array}{c}\text { Total length } \\
\text { of net } \\
(\mathrm{m})\end{array}$ & $\begin{array}{l}\text { Stretched net } \\
\text { circumference } \\
(\mathrm{m})\end{array}$ & $\begin{array}{c}\text { HR } \\
\text { length } \\
(\mathrm{m})\end{array}$ & $\begin{array}{c}\text { GR } \\
\text { length } \\
(\mathrm{m}) \\
\end{array}$ & $\begin{array}{c}\text { Total buoyancy } \\
\text { of floats } \\
(\mathrm{kg})\end{array}$ & $\begin{array}{c}\text { Total weight } \\
\text { of sinkers } \\
(\mathrm{kg})\end{array}$ & $\frac{\lambda^{\prime}}{\lambda^{\prime \prime}}$ & $\frac{\mathrm{V}^{\prime}}{\mathrm{V}^{\prime \prime}}$ & $\frac{\mathrm{D}}{\mathrm{L}}$ \\
\hline Full scale & 16 & 19.25 & 14 & 16 & 3.8 & 12 & & & \\
\hline Model scale & 2 & 2.41 & 1.75 & 2 & $23.67 \times 10^{-3}$ & $74.49 \times 10^{-3}$ & $1 / 8$ & 0.62 & 0.028 \\
\hline
\end{tabular}
traditional bottom trawl net. The bracketed numbers are mesh sizes (mm). Panel of elements: A-upper and lower wings, Bside net, C-Baiting, D-Belly, E-Codends, and a- Net circumference

Table 3. The comparative values of full scale and experimental model scale of bottom trawl.

\section{Experimental conditions}

A trawl model was tested experimentally in water circular tank belongs to the Faculty of Fishery, Kagoshima University, Japan (Figure 3). The tank consists of 2 impellers type vertical circulating water channel with 2 sets drive motor D.C. 22 kilowatt. The main body dimension: $14.8 \mathrm{~m}$ long, $2.0 \mathrm{~m}$ wide and $5.9 \mathrm{~m}$ high, while the measuring section: $6 \mathrm{~m}$ long, 2 $\mathrm{m}$ wide and $1 \mathrm{~m}$ deep. It is constructed of reinforced concrete with approximately 80,000 liters fresh water in capacity. The central observation channel is $2 \mathrm{~m}$ wide and the right and the left water ways are each $1 \mathrm{~m}$ wide. The water flows symmetrically into the central section forming a straight water channel for experimental works. The flow is made by two sets of rotating propellers driven by an alternating current motor. The flow speed of 0 - $2.2 \mathrm{~m} \mathrm{~s}^{-1}$ can be accurately controlled and adjusted by an ultrasonic current meter. Both side walls of observing channel which are 
It is made of wood $(70 \times 45 \mathrm{~cm})$, the lower part fulfilled with cement mixed with leads to have touch connection power to the sea bottom and the upper part put two plastic floats with diameter $100 \mathrm{~mm}$ to hold it stands vertically and total weight was $20 \mathrm{~kg}$ per unit. The hand rope of $2 \mathrm{~m}$ long made of Polyethylene with diameter of $8 \mathrm{~mm}$, attached together with otter boards.

\section{Main dimensions of the model net}

The original full scale net plans were transformed into experimental model scale based on the Tauti's Comparative Method (Tauti, 1934). The ratio between experimental model scale (') and full scale (") were described as follows:

1. Reducing scale is $\lambda^{\prime} / \lambda^{\prime \prime}$

2. Ratio of twine diameter, $D$ and mesh size, $L$ is $D^{\prime} / D^{\prime \prime}=L^{\prime} / L^{\prime \prime}$

3. Ratio of velocity, $V$ is $V^{\prime} / V^{\prime \prime}=$ $\sqrt{D^{\prime} / D^{\prime \prime} \cdot\left(\rho^{\prime}-1\right)\left(\rho^{\prime \prime}-1\right)}$

4. Ratio of rope diameter, $D_{1}$ is $D_{1}^{\prime} / D_{l}^{\prime \prime}=$ $\left.\sqrt{\lambda^{\prime} / \lambda^{\prime \prime} \cdot\left(\rho_{1}^{\prime \prime}\right.}-1\right)\left(\rho_{1}^{\prime}-1\right) \cdot V^{\prime 2} / V^{\prime \prime 2}$

5. Ratio of sinking and floating power, $F$ and that of the force acting on the net, $R$ is $F^{\prime} /$ $F^{\prime \prime}=R^{\prime} / R^{\prime \prime}=\left(\lambda^{\prime 2} / \lambda^{\prime \prime 2}\right)\left(V^{\prime 2} / V^{\prime 2}\right)$

Where $\rho$ is the specific gravity of netting cord, and $\rho_{1}$ is the specific gravity of the rope.

Table 2. The specification of traditional bottom trawl net used in Kotabaru, Indonesia

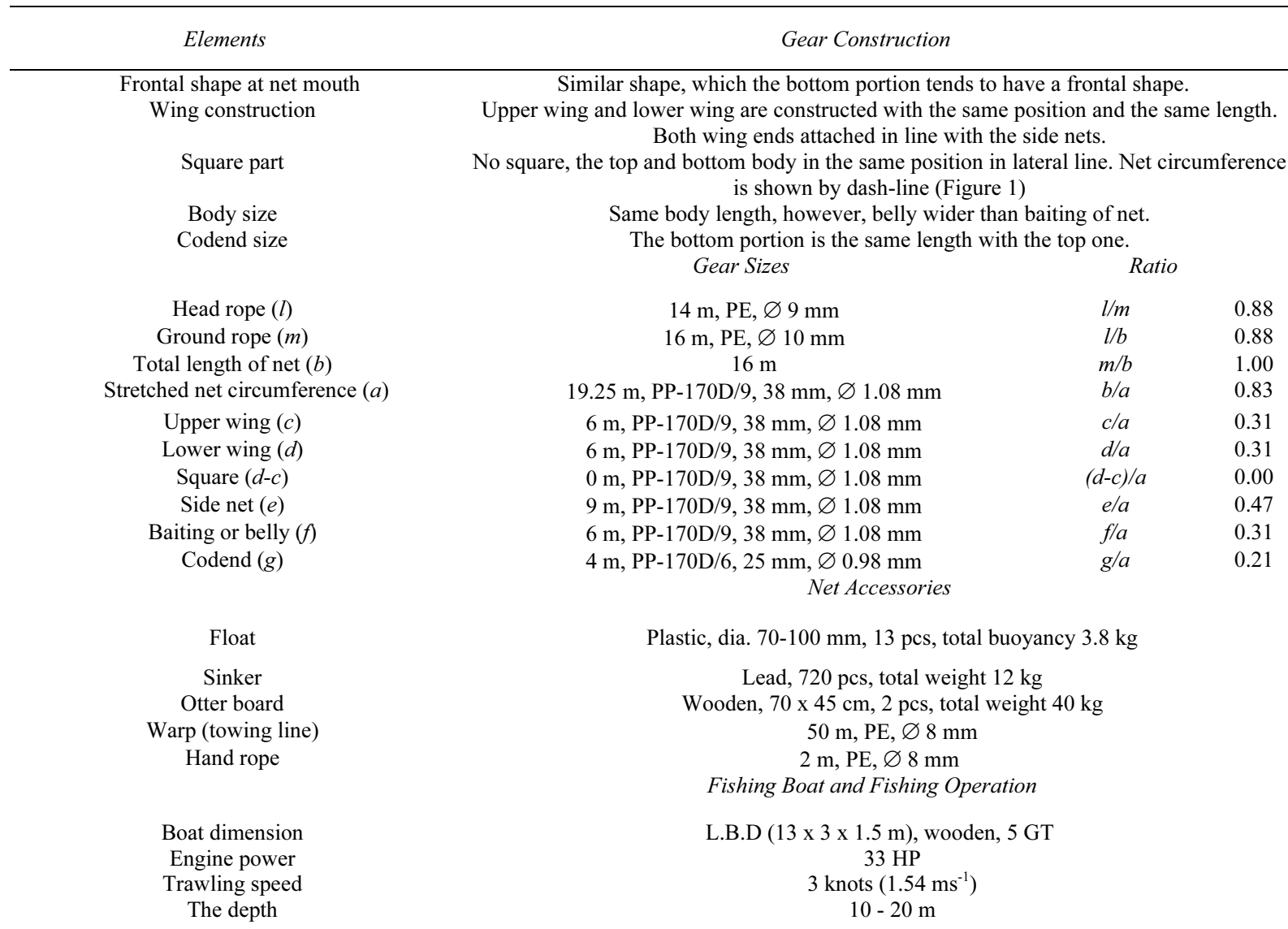


performance of the demersal bottom trawl net used in Kotabaru under towing conditions to improve the gear construction and its catching efficiency.

Table 1. The trend status of shrimp fishing in Kotabaru Regency during 2011-2015

\begin{tabular}{clccccc}
\hline \multirow{2}{*}{ No } & \multicolumn{2}{c}{ Variables } & \multicolumn{3}{c}{ Year } \\
\cline { 3 - 6 } & & 2011 & 2012 & 2013 & 2014 & 2015 \\
\hline 1. & Annual production (ton) & 192.94 & 337.64 & 590.87 & 709.04 & 4930 \\
2. & Capture fishery households & 5492 & 5495 & 5945 & 4591 & 11836 \\
3. & Fishing boats (<5 GT) & 4966 & 4970 & 4790 & 3,892 & 6749 \\
4. & Number of trawl nets & 589 & 589 & 589 & 4079 & 4079 \\
\hline
\end{tabular}

Source: BPS-Statistic of Kotabaru Regency

\section{Materials and Methods}

\section{Gear Characteristics}

A sample of bottom trawls from Kotabaru Regency was selected for study purpose. It was towed at the speed of 3 knots with engine power of $33 \mathrm{HP}$ and used for catching red snapper, barramundi, black tiger prawn, banana prawn, and endeavour shrimp. It is generally categorized in small size groups of the whole trawls (Figs. 1A and B). According to fisherman information, fishing season for fish is from September to November, while for shrimps is from August to January. The gear specification is described in Table 2. The net was constructed without using the lacing lines. Lacing twine used for joining to both selvedges of belly-baiting and side nets. Actually, the lacing lines were originally meant to strengthen the netting for hauling. The function of the lacing lines has been extended to increase the height of net opening by better distributing the towing forces which had previously been concentrated on the head rope and ground rope. In the gear construction, the ratio of head rope $(H R)$ to ground rope $(G R)$ is important factor for having a good performance of the net mouth.
The suggested ratio of this is 0.87 for twoseam trawl and 0.83 for four-seam trawl (Nomura et al., 1977). In the present study, the $H R / G R$ ratio was 0.88 instead of the suggested ratio. The otter boards are used to spread the wing tips horizontally, and simultaneously to keep it in contact with the seabed.
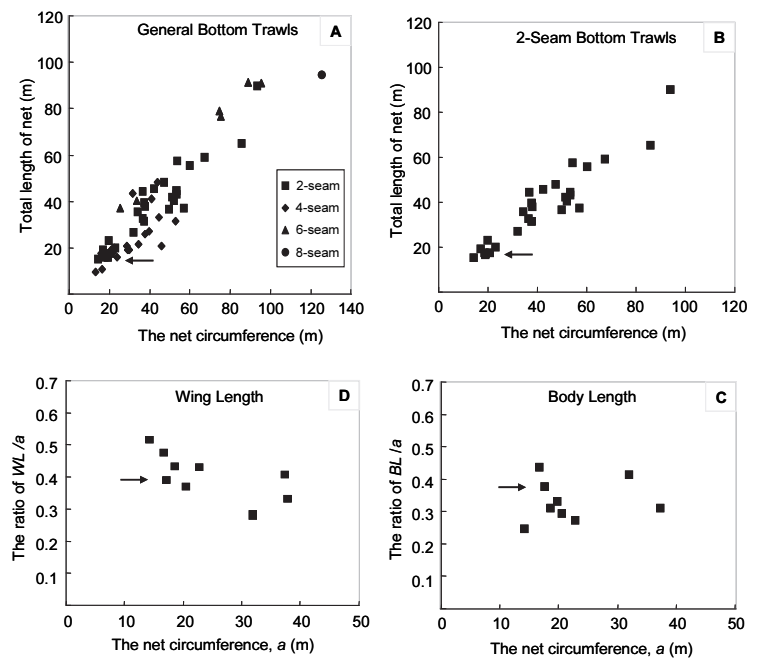

Figure 1. In clockwise: A. the position of bottom trawl from Kotabaru in general bottom trawls, B. Its position among other 2-seam bottom trawls, $\mathbf{C}$. Comparative ratio of body length to the net circumference $(B L / a)$ among 2-seam shrimp trawls and $\mathbf{D}$. Comparative ratio of wing length to the net circumference $(W L / a)$ among the trawls. The arrows pointed to the position of the current bottom trawl net. 
cable-body system (Chin et al., 2000; Suzuki et al., 2003), to evaluate effects of drag coefficient of netting for dynamic similarity on model testing of trawl nets (Hu et al., 2001) and to reduce hydrodynamic force acting on bottom trawl net (Ebata et al., 2013).

At the same time, a series of field experiments with trawl nets are also being carried out to obtain some fundamental suggestions on the gear efficiency and effectiveness of the trawls. Higo (1971) reported that the four-seam trawl has a better gear efficiency than the two-seam trawl in term of net mouth performance. Later on, the net height of six-seam trawl net was found to be higher than that of four-seam trawl net (Muchtar et al., 1973). Shahardin (1983) suggested employing the double rigged type shrimp trawl over the single rigged in terms of the sweeping area and catch ability at the same fishing ground and the same trawler.

According to Walsh (1996) changes in sampling trawl geometry and performance can affect the catching efficiency and also contribute to the bias and sampling variance associated with the survey estimates. Balash et al. (2011) reported that in the 'W' trawl design, drag was better redirected through the centerline to the tongues for T45 mesh body sections compared to T0: $59 \%$ and $40 \%$ of the total drag was transferred respectively. In case of net webbing selection, the knotless trawl is preferable to use instead of the knotted trawl because of having better fish catching efficiency (Fuwa et al., 2013). Dealing with fuel saving, Ebata et al., (2013) suggested using "Dyneema" (ultra-high strength polyethylene fiber) to save fuel consumption of operation since it was able to reduce up to $24.7 \%$ of the hydrodynamic resistance of a bottom trawl net, while the shape of the net did not change. Khaled et al. (2012) optimized cable length for trawl fuel consumption reduction. According to Eliasson et al. (2015) the use of draft tube on trawler propulsion system can save fuel up to $20 \%$. While Broadhurst et al. (2014) measured the drag of single-, twin-, triple- and quad-rigs in the field and demonstrated fuel savings up to $26 \%$ from using the high-order, multiple-net rigs. Some studies focused on the size selectivity in the codends (Sala and Lucchetti, 2011; Dereli et al., 2016); or work function of otter boards (Takahashi et al., 2013; Mellibovsky et al., 2015; McHugh et al., 2015a). Other researches emphasized on bycatch reduction by configuring the mesh sizes, side taper and wing depth of trawls (Broadhurst et al., 2014); by using grid size-sorting system (Madsen and Hansen, 2001; He and Balzano, 2012); bridles floatation (He et al., 2014) or A 'simple anterior fish excluder' (SAFE) (McHugh et al., 2015b) during trawling operations.

A total of 4,079 bottom trawls operated in Kotabaru, South Kalimantan (BPS-Statistic of Kotabaru Regency, 2015) and have been very important commercial fishing gear for catching shrimp and demersal fish. The annual production of shrimp in Kotabaru increases proportionally with increasing the number of trawl nets as shown in Table 1. Technically many people do not know well about hydrodynamic performance of bottom trawl due to lack of information of what full scale trawl (prototype) look like under trawling condition (Ahmadi et al., 2005). We updated and extended database on a bottom trawl model testing to get more knowledge in this area of study. The main objective of this research was to describe the hydrodynamic 


\title{
Hydrodynamic Performance of Kotabaru's Traditional Bottom Trawl under the Flume Tank Experiment
}

\author{
Ahmadi \\ Faculty of Marine and Fisheries, Lambung Mangkurat University, Banjarbaru 70714, \\ South Kalimantan, Indonesia. Email: ahmadi@unlam.ac.id. \\ OCHID iD: orcid.org/0000-0002-9117-2742.
}

\begin{abstract}
Hydrodynamic performance of a $1 / 8$ scale model of traditional bottom trawl was investigated in a flume tank. It was to represent prototype of a bottom trawl with a low engine power of $33 \mathrm{HP}$ at a towing speed of 3-knot, which is commonly used in Kotabaru, Indonesia. At a towing speed of 3-knot ( $96 \mathrm{~cm} \mathrm{~s}^{-1}$ in model scale), the net heights at different wing tips distances varied from 7.0 to $9.2 \mathrm{~cm}$, the projective areas of net mouth from $6.35 \times 10^{2}$ to $8.44 \times 10^{2} \mathrm{~cm}^{2}$, water filtering volume from $32.04 \times 10^{3}$ to $40.55 \times 10^{3} \mathrm{~m}^{3}$ and total net resistance from $11.07 \times 10^{2}$ to $13.46 \times 10^{2} \mathrm{~g}$. In the present study, the values of $H / a$ ratio obtained was low $(0.029$ to 0.038$)$ because there was no square part on the net body construction. The net height was $3.4 \%$ of net circumference and getting lower at higher towing speeds. Water flow velocity and pressure distribution around trawl can alternate mesh shape from diamond to parallelogram. The average exponent value 1.37 was less than the suggested value (2.0); thus, the shape of net body under towing condition should be refined.
\end{abstract}

Keywords: model scale, flume tank, gear efficiency, net circumference, bottom trawl, Kotabaru

\section{Introduction}

It is generally accepted that the demersal trawl is one of the most productive fishing gears for catching shrimp and demersal fish. Annual bottom trawl surveys are commonly used to measure temporal variation in stock size, mortality and recruitment, along with other biological characteristics, of various groundfish stocks under management regulation (Walsh, 1996). The improvement of the gear in construction should be effectively matched with the fish behavior of various species (He et al., 2008; Özbilgin, 2013; Bayse et al., 2016).

When designing trawl net, one must select the adequate size of twine for fishing net which will have enough strength against the tension of netting cord caused by external forces such as hydraulic resistance of net to the current, tension of net due to hauling and setting set operations, and some other unexpected impact of external forces. Hydrodynamic force on the gear arises from the movement of the fishing gear through the water or from the movement of water with respect to gear. It originates in the pressure required to divert the water around the solid components of the gear. Its magnitude and direction determine to a considerable degree the loads imposed on the gear and its position in space, which is greatly affecting the fishing efficiency (Fridman, 1986).

Some studies on physical characteristics (hydrodynamic resistance) of fishing gear in a flume tank are being performed with specificpurpose like the pelagic net (Reid, 1977), gill nets (Stewart and Ferro, 1985), mid trawl (Hu et al., 2001), trolling depressor (Fuwa et al., 2002), and shrimp trawl net (Suzuki et al., 2003; Fiorentini et al., 2004). Other related studies have also been carried out in the flume tank to determine numerical model application for improved trawling systems of a towed 